\title{
Editorial: Hydrothermal microbial ecosystems
}

\author{
Andreas Teske ${ }^{1 *}$ and Anna-Louise Reysenbach ${ }^{2}$ \\ ${ }^{1}$ Department of Marine Sciences, University of North Carolina, Chapel Hill, NC, USA, ${ }^{2}$ Biology Department, Portland State \\ University, Portland, OR, USA
}

Keywords: hydrothermal vent, extremophiles, biogeography, chemosynthesis, archaea, bacteria, Guaymas basin

\section{OPEN ACCESS}

Edited by:

Virginia P. Edgcomb

Woods Hole Oceanographic Institution, USA

Reviewed by: Maria Pachiadaki,

Woods Hole Oceanographic Institution, USA

${ }^{*}$ Correspondence: Andreas Teske, teske@email.unc.edu

Specialty section:

This article was submitted to Extreme Microbiology, a section of the journal Frontiers in Microbiology

Received: 12 June 2015 Accepted: 12 August 2015 Published: 01 September 2015

Citation:

Teske A and Reysenbach A-L (2015) Editorial: Hydrothermal microbial ecosystems. Front. Microbiol. 6:884. doi: 10.3389/fmicb.2015.00884
The papers in the "Hydrothermal Vent" research topic cover a range of microbiological research in deep and shallow hydrothermal environments, from high temperature "black smokers," to diffuse flow habitats and episodically discharging subsurface fluids, to the hydrothermal plumes. Together they provide a snapshot of current research interests in a field that has evolved rapidly since the discovery of hydrothermal vents in 1977.

The topic opens with a review by Dick et al. (2013) on hydrothermal plumes and their microbial communities in the deep sea. The review synthesizes recent advances in the microbial ecology, physiology, and genomics of the mostly chemosynthetic bacteria that have adapted to the supply of carbon and energy sources in the turbulently mixed vent plume. These pelagic communities are distinct from those in hydrothermal chimneys, sediments and the subsurface, yet they show some taxonomic and physiological linkages. This review is followed by four papers that shed new light on microbial ecosystems in mixed vent fluids. The high-flow example is represented by sulfiderich subsurface vent fluids discharging in "snow blower" bursts dominated by sulfur-oxidizing, microaerobic, and often moderately thermophilic Epsilonproteobacteria (Meyer et al., 2013a). Similar epsilonproteobacterial communities, dominated by the chemosynthetic, sulfur-oxidizing genera Sulfurimonas and Sulfurovum, were also found in cool, diffusive flow at the same location, Axial Seamount on the Juan de Fuca Ridge (Akerman et al., 2013). The authors proposed that both diffuse flow and episodic high-flow events tap into the same subsurface community of microaerobic sulfur oxidizers. Epsilonproteobacteria accounted again for most of the microbial taxa found in diffuse flow samples from the basalt-hosted vent sites of $9^{\circ} \mathrm{N}$ East Pacific Rise, but not in similar habitats in the organic-rich hydrothermal sediments of Guaymas Basin in the Gulf of California, where other bacterial groups and hyperthermophilic archaea predominated (Campbell et al., 2013). Changing flow paths and reservoirs for subseafloor mixed fluids and their microbiota can also change the composition of venting microbial communities over time as reported by Kato and colleagues. At Suiyo Seamount in the Izu-Bonin Arc within the Western Pacific, a hot and reducing subsurface reservoir accessed by drilling underwent increasing seawater in-mixing over several years. Consequently, the crustal fluid community of sulfur-oxidizing chemolithotrophs changed to a mixed assemblage harboring abundant marine heterotrophic bacteria (Kato et al., 2013).

While deep-sea hydrothermal vent sites are difficult to access and to sample, shallow water hydrothermal vents that can be reached by scuba divers provide an accessible alternative environment to study. Perhaps the best-investigated of these shallow-water vents are found on the coast of the Greek island Milos in the Aegean Sea, where hot, briny, reducing, $\mathrm{CO}_{2}$-rich vent fluids permeate the sandy seafloor sediments of Paleochori Bay. Giovannelli et al. (2013) show that in the surficial sediments the microbial community is dominated by Epsilonproteo-bacteria (genus Sulfurovum) similar to those seen in deep-sea vents; however proteobacterial lineages that are distinct from those of deep-sea vents were also detected. In contrast, in the deeper sediment layers of this sample vent field, Price et al. (2013) find Epsilonproteobacteria, but also Firmicutes, Planctomycetes, and Bacteroidetes coexisting with thermophilic archaea. In addition, arsenite-oxidizing bacteria were identified by 
functional gene analysis in these arsenite-rich sediments. Sitespecific adaptations of vent communities are also the focus of Bayraktarov et al. (2013), as they examine the $\mathrm{pH}$ preferences of sulfate-reducing microbial communities in the Milos vent sediments. In the proximity of $\mathrm{CO}_{2}$-rich, low- $\mathrm{pH}$ fluids, the sulfate-reducing microbial communities show maximal activities at a distinctly lower $\mathrm{pH}$ range than at less acidic control sites not impacted by $\mathrm{CO}_{2}$-rich vent fluids.

Among deep-sea vent sites, the sediment-covered Guaymas Basin hydrothermal vents in the central Gulf of California is unusual; the buried organic matter in these sediments are hydrothermally processed to petroleum compounds, lowmolecular weight organic acids, short-chain alkanes, methane and ammonia. These substrates sustain a unique microbial ecosystem that combines the characteristics of communities from hydrocarbon seeps and mid-ocean ridge hydrothermal vents. Meyer and colleagues demonstrate that the microbial populations in Guaymas sediments show a high degree of microbial connectivity and population overlap within an area of a few $100 \mathrm{~m}-\mathrm{a}$ consequence of vigorous venting, rapid dispersal via bottom currents, and closely spaced hydrothermal features (Meyer et al., 2013b). Abundant aromatic and aliphatic hydrocarbons in Guaymas Basin sediments and chimneys enrich for microbial specialists-especially sulfate-reducing bacteriathat utilize hydrocarbons, remineralize them to $\mathrm{CO}_{2}$, or assimilate them into microbial biomass; these communities feature prominently in metagenomic analyses of hydrocarbonrich Guaymas chimneys (He et al., 2013). The ammonia-rich and methane-rich hydrothermal fluids at Guaymas sustain ammoniaoxidizing bacteria (anammox) and methane- oxidizing archaea (ANME) in the surficial sediments. The anammox bacteria combine ammonia and nitrite to $\mathrm{N} 2$, and are usually better known from marine oxygen minimum zones and stratified water columns (Russ et al., 2013). A recently identified, hightemperature tolerant clade of the cosmopolitan seep methaneoxidizing archaeal lineage ANME-1 is widespread at Guaymas Basin. The "ANME_1Guaymas" have been enriched using insitu colonization chambers that were placed into surficial hydrothermal sediments on the seafloor (Callac et al., 2013). One of the relatively few analogous environments to Guaymas Basin, the alkane-rich hydrothermal sediments of the Middle Valley vent field on the northern Juan de Fuca ridge, provide the opportunity to study similar microbial communities and processes. In anaerobic batch reaction incubations, short alkanes (ethane, propane, butane) were consumed within a mesophilic to thermophilic temperature range, probably by sulfate-reducing bacteria (Adams et al., 2013).

Hydrothermal vents are suitable model systems to explore microbial biogeography because they are island habitats in the deep sea; their thermophilic, chemosynthetic or special substrate-adapted microbial inhabitants likely cannot survive, and certainly cannot thrive in the cold, oxidized sediments and bottom waters of the deep sea that separate hydrothermal hot spots. In this volume several papers evaluate the controls of microbial community structure, geographic distance vs. environmental selection pressures in different habitats such as tubeworm trophosomes, sulfides, and ferric iron hydroxides. Sulfur-oxidizing endosymbionts of vestimentiferan tubeworms, which thrive in seep and vent habitats, showed a clear separation into different Gulf of Mexico and Mediterranean genotypes by $16 \mathrm{~S}$ rRNA gene, mitochondrial cytochrome $\mathrm{C}$ oxidase, and functional genes of the two coexisting $\mathrm{CO}_{2}$ assimilation pathways that coexist in the endosymbiont, the Calvin-BensonBassham and the reverse TCA cycle (Thiel et al., 2012). Mino et al. (2013) use multi-locus sequence analysis to show that isolates of the chemosynthetic thermophilic genus Persephonella from different vent sites in the Okinawa Trough and in the distant Southern Mariana Trench in the western Pacific undergo sympatric speciation. Similarly, Wagner et al. (2013) use multilocus sequence analysis to demonstrate genetic differentiation among strains of the thermophilic fermenting Firmicute, Thermoanaerobacter uzonensis, from different terrestrial hot spring locations within the Uzon Caldera in Kamtchatka. In this case, genetic divergence did not correlate with geographic separation on these short distances of mostly a few $100 \mathrm{~m}$. Sylvan et al. (2013) describe how the biogeographical boundary of the north-south transition from basalt-hosted to andesite-hosted vents on the Eastern Lau spreading Center and Valu Fa ridge, appears to select for distinct bacterial taxa on silicate rocks, whereas inactive sulfides show major differences in bacterial community structure between the surface and the interior sulfide mineral matrix. Members of the Zetaproteobacteria, including the microaerobic and chemolithotrophic iron oxidizer Mariprofundus ferrooxidans, fall into different 16S rRNA phylotypes of Zetaproteobacteria from the Southern Mariana Arc, the Hawaiian hot spot, and from the Vai'lulu/Tonga Arc/East Lau Spreading Center/Kermadec Arc. This study shows that the Zetaproteobacteria from these sites form mutually intertwined microclusters on the $16 \mathrm{~S}$ rRNA gene level, suggesting more detailed genomic analyses to explore their biogeography in fine resolution (Singer et al., 2013).

This research topic includes methodological assessments. Molecular surveys of biogeographic patterns and dominant microbial populations depend critically on the molecular tools used. To document inherent methodological biases, Hoshino and Inagaki (2013) perform a comparative molecular analysis of bacterial populations in hydrothermal sediments of Yonaguni Knoll in the Southern Okinawa Trough. By comparing the phylotypes recovered by conventional reverse-transcription PCR with domain-specific primers and by previous poly-A tailing of the extracted rRNA, they find different clades of Deltaproteobacteria and detect unusual archaea in the poly-A tailing assay that may escape detection by conventional PCR or RT-PCR using domain-specific primers.

The last two contributions to this research topic discuss microbial groups that are not commonly considered as components of hydrothermal microbiota, marine heterotrophic bacteria and pelagic marine archaea. When cosmopolitan, heterotrophic marine bacteria appear in molecular diversity surveys of hydrothermal vents or other extreme habitats, they are regarded as "hitchhikers" or potentially contaminants from entrainment of seawater. Handley and Lloyd (2013) examine the cosmopolitan marine genus Marinobacter and find that these versatile bacteria-commonly regarded as aerobes or fermenters-include nitrate-reducing and metal-reducing representatives from low-temperature vents, marine sediments 
and mid-ocean ridge basalts. This genus is therefore wellsuited to colonize aerobic- to-anoxic gradients in most marine environments, including hydrothermal vents. Likewise, the Thaumarchaeota-marine archaea that are ubiquitous in the cold and oxic marine water column-have been found in surficial marine sediments, hydrothermal plumes, and hot spring sediments. Ragon et al. (2013) report a new phylotype within the terrestrial hot spring branch of the Thaumarchaeota, detected in deep hot $\left(60^{\circ} \mathrm{C}\right)$ spring waters in Naica Mine, Chihuahua, Mexico. Thus, the Thaumarchaeota emerge as one of the most adaptable archaeal lineages that inhabit marine and terrestrial, oxic and anoxic, cold, and hydrothermal habitats.

These papers represent a sampler of ongoing microbiological research in hydrothermal environments, and demonstrate the wide multidisciplinary context of this field. Hydrothermal

\section{References}

Adams, M. M., Hoarfrost, A. L., Bose, A., Joye, S. B., and Girguis, P. R. (2013). Anaerobic oxidation of short-chain alkanes in hydrothermal sediments: potential influences on sulfur cycling and microbial diversity. Front. Microbiol. 4:110. doi: $10.3389 /$ fmicb.2013.00110

Akerman, N. H., Butterfield, D. A., and Huber, J. A. (2013). Phylogenetic diversity and functional gene patterns of sulfur-oxidizing subseafloor Epsilonproteobacteria in diffuse hydrothermal fluids. Front. Microbiol. 4:185. doi: $10.3389 /$ fmicb. 2013.00185

Bayraktarov, E., Price, R. E., Ferdelman, T. G., and Finster, K. (2013). The pH and $\mathrm{pCO}_{2}$ dependence of sulfate reduction in shallow-sea hydrothermal $\mathrm{CO}_{2}$ venting sediments (Milos Island, Greece). Front. Microbiol. 4:111. doi: 10.3389/ fmicb.2013.00111

Callac, N., Rommevaux-Jestin, C., Rouxel, O., Lesongeur, F., Liorzou, C., Bollinger, C., et al. (2013). Microbial colonization of basaltic glasses in hydrothermal organic-rich sediments at Guaymas Basin. Front. Microbiol. 4:250. doi: 10.3389/ fmicb.2013.00250

Campbell, B. J., Polson, S. W., Allen, L. Z., Williamson, S. J., Lee, C. K., Wommack, K. E., et al. (2013). Diffuse flow environments within basalt- and sediment-hosted hydrothermal vent ecosystems harbor specialized microbial communities. Front. Microbiol. 4:182. doi: 10.3389/fmicb.2013.00182

Dick, G. J., Anantharaman, K., Baker, B. J., Li, M., Reed, D. C., and Sheik, C. S. (2013). The microbiology of deep-sea hydrothermal vent plumes: ecological and biogeographical linkages to seafloor and water column habitats. Front. Microbiol. 4:124. doi: 10.3389/fmicb.2013.00124

Giovannelli, D., d'Errico, G., Manini, E., Yakimov, M., and Vetriani, C. (2013). Diversity and phylogenetic analyses of bacteria from a shallow-water hydrothermal vent in Milos Island (Greece). Front. Microbiol. 4:184. doi: 10.3389/fmicb.2013.00184

Handley, K. M., and Lloyd, J. R. (2013). Biogeochemical implications of the ubiquitous colonization of marine habitat and redox gradients by Marinobacter species. Front. Microbiol. 4:136. doi: 10.3389/fmicb.2013.00136

He, Y., Xiao, X., and Wang, F. (2013). Metagenome reveals potential microbial degradation of hydrocarbon coupled with sulfate reduction in an oilimmersed chimney from Guaymas Basin. Front. Microbiol. 4:148. doi: 10.3389/ fmicb. 2013.00148

Hoshino, T., and Inagaki, F. (2013). A comparative study of microbial diversity and community structure in marine sediments using poly(A) tailing and reverse transcription PCR. Front. Microbiol. 4:160. doi: 10.3389/ fmicb.2013.00160

Kato, S., Nakawake, M., Kita, J., Yamanaka, T., Utsumi, M., Okamura, K., et al. (2013). Characteristics of microbial communities in crustal fluids in a deepsea hydrothermal field of the Suiyo Seamount. Front. Microbiol. 4:85. doi: 10.3389/fmicb.2013.00085

Meyer, J. L., Akerman, N. H., Proskurowski, G., and Huber, J. A. (2013a). Microbiological characterization of post-eruption "snowblower" vents at Axial Seamount, Juan de Fuca Ridge. Front. Microbiol. 4:153. doi: 10.3389/fmicb. 2013.00153 vents are not disconnected in time and space from the wider deep-sea ecosystem, without geological and biogeographical context. The research papers assembled here integrate geology, biogeochemistry, microbial physiology, microbial genomics and systematics across spatial scales that zoom in and out depending on the research question at hand. Perhaps no other field is so intertwined with the geological and geochemical evolution of the oceans, and promises so many biochemical and physiological discoveries still to be made within the unexhausted richness of extreme microbial life.

\section{Acknowledgments}

The editors' hydrothermal vent research and their efforts to develop this research topic were supported by NSF grants OCE0647633 and 1334371 (AT) and OCE-1235432 (AR).

Meyer, S., Wegener, G., Lloyd, K. G., Teske, A., Boetius, A., and Ramette, A. (2013b). Microbial habitat connectivity across spatial scales and hydrothermal temperature gradients at Guaymas Basin. Front. Microbiol. 4:207. doi: 10.3389/ fmicb.2013.00207

Mino, S., Makita, H., Toki, T., Miyazaki, J., Kato, S., Watanabe, H., et al. (2013). Biogeography of Persephonella in deep-sea hydrothermal vents of the Western Pacific. Front. Microbiol. 4:107. doi: 10.3389/ fmicb.2013.00107

Price, R. E., Lesniewski, R., Nitzsche, K. S., Meyerdierks, A., Saltikov, C., Pichler, T., et al. (2013). Archaeal and bacterial diversity in an arsenic-rich shallow-sea hydrothermal system undergoing phase separation. Front. Microbiol. 4:158. doi: 10.3389/fmicb.2013.00158

Ragon, M., Van Driessche, A. E. S., García-Ruíz, J. M., Moreira, D., and LópezGarcía, P. (2013). Microbial diversity in the deep-subsurface hydrothermal aquifer feeding the giant gypsum crystal-bearing Naica Mine, Mexico. Front. Microbiol. 4:37. doi: 10.3389/fmicb.2013.00037

Russ, L., Kartal, B., op den Camp, H. J., Sollai, M., Le Bruchec, J., Caprais, C. J., et al. (2013). Presence and diversity of anammox bacteria in cold hydrocarbon-rich seeps and hydrothermal vent sediments of the Guaymas Basin. Front. Microbiol. 4:219. doi: 10.3389/ fmicb.2013.00219

Singer, E., Heidelberg, J. F., Dhillon, A., and Edwards, K. J. (2013). Metagenomic insights into the dominant $\mathrm{Fe}(\mathrm{II})$ oxidizing Zetaproteobacteria from an iron mat at Lo'ihi, Hawai'i. Front. Microbiol. 4:52. doi: 10.3389/ fmicb.2013. 00052

Sylvan, J. B., Sia, T. Y., Haddad, A. G., Briscoe, L. J., Toner, B. M., Girguis, P. R., et al. (2013). Low temperature geomicrobiology follows host rock composition along a geochemical gradient in Lau Basin. Front. Microbiol. 4:61. doi: 10.3389/fmicb.2013.00061

Thiel, V., Hügler, M., Blümel, M., Baumann, H. I., Gärtner, A., Schmaljohann, R., et al. (2012). Widespread occurrence of two carbon fixation pathways in tubeworm endosymbionts: lessons from hydrothermal vent associated tubeworms from the Mediterranean Sea. Front. Microbiol. 3:423. doi: 10.3389/ fmicb.2012.00423

Wagner, I. D., Varghese, J. B., Hemme, C. L., and Wiegel, J. (2013). Multilocus sequence analysis of Thermoanaerobacter isolates reveals recombining, but differentiated, populations from geothermal springs of the Uzon Chaldera, Kamtchtka, Russia. Front. Microbiol. 4:169. doi: 10.3389/ fmicb.2012. 00169

Conflict of Interest Statement: The authors declare that the research was conducted in the absence of any commercial or financial relationships that could be construed as a potential conflict of interest.

Copyright (c) 2015 Teske and Reysenbach. This is an open-access article distributed under the terms of the Creative Commons Attribution License (CC BY). The use, distribution or reproduction in other forums is permitted, provided the original author(s) or licensor are credited and that the original publication in this journal is cited, in accordance with accepted academic practice. No use, distribution or reproduction is permitted which does not comply with these terms. 